\title{
Partial Pulpotomy in a Permanent Molar with Hyperplastic Pulpitis: A Case Report
}

\author{
Hiperplastik Pulpitisli Daimi Molar Dişte Kısmi Pulpotomi: Bir Olgu Sunumu
}

Ilgın AKÇAY Mehmet Emin KAVAL

Ege Üniversitesi Diş Hekimliği Fakültesi, Endodonti AD, IZMiR

\begin{abstract}
Partial pulpotomy is a pulp therapy in which a portion of damaged and inflamed coronal pulp tissue is removed surgically. A 22year-old female suffering from profound caries defect in her mandibular second molar was referred to our clinic. Tooth responded within normal limits to electrical pulp tests. No history of spontaneous pain, mobility or tenderness to percussion was noted. Radiographic examination revealed an enlargement towards the periodontal ligament of the tooth. It was diagnosed as hyperplastic pulpitis. A local anesthetic without vasoconstrictor was applied to the tooth. MTA was placed over the amputated pulp tissue and covered temporarily with zinc oxide-eugenol cement. The patient was re-called after 24 hours to asses if there was any sense of postoperative pain caused by the treated tooth. No postoperative sensitivity was noted. The temporary restoration was removed under aseptic conditions; MTA was then covered with glass ionomer cement. In the same appointment, the tooth was restored with resin composite. Examinations 1 year after the treatment revealed success with the observance of normal function, aesthetics with a vital pulp and healthy surrounding periodontal structures. MTA may be useful as a substitute for calcium hydroxide in pulpotomy procedures of permanent molars with hyperplastic pulpitis.
\end{abstract}

Keywords: Hyperplastic pulpitis, pulpotomy, MTA

\section{Özet}

Kısmi pulpotomi zarar görmüş enflame koroner pulpanın cerrahi olarak uzaklaştııılığı, vital bir pulpa tedavisidir. Yirmi iki yaşında kadın hasta alt ikinci molar dişindeki derin çürük şikâyeti ile kliniğimize başvurdu. Diş elektrik pulpa testine normal sınırlar içerisinde yanıt verdi. Hastanın hikâyesinden spontan ağrı, mobilite ya da perküsyona hassasiyet olmadığı saptandı. Radyolojik muayene dişi çevreleyen periodontal ligamentte bir miktar genişleme olduğunu gösterdi. Dişe hiperplastik pulpa tanısı konuldu. Dişe vazokonstriktörsüz bir lokal anestezik uygulandı. Ampüte edilen pulpa dokusu üzerine MTA yerleştirildi ve kavite çinko oksit öjenol içerikli geçici siman ile kapatıldı. Hasta, 24 saat sonra, ilgili dişinden kaynaklı herhangi bir postoperatif şikayeti olup olmadığını öğrenmek üzere çağrıldı. Herhangi bir hassasiyet olmadığı gözlendi. Geçici dolgu aseptik koşullarda kaldırılıp, MTA üzerine cam iyonomer kaide yerleştirildi. Aynı seansta diş kompozit rezin ile restore edildi. Bir yıllık kontrollerin sonunda, çevre periodontal dokularının sağlıkı olduğu, dişin vitalitesini koruduğu; estetik ve fonksiyon açısından memnun edici düzeyde olduğu gözlendi. Hiperplastik pulpitisli daimi molar dişlerde gerçekleştirilecek pulpotomi işlemlerinde MTA, kalsiyum hidroksite alternatif olabilir.

Anahtar sözcükler: Hiperplastik pulpitis, pulpotomi, MTA

\section{Introduction}

Partial pulpotomy is a vital pulp therapy in which a portion of damaged and inflamed coronal pulp tissue is removed surgically. The remaining pulp surface is covered with a suitable dressing agent to promote healing and to maintain vitality of the pulp tissue. ${ }^{1}$

Calcium hydroxide has become prominent among various materials for vital pulp treatments. ${ }^{2}$ Despite the usage of calcium hydroxide dressing 
in vital pulp therapies for a long time period, the caustic actions of calcium hydroxide makes it controversial. ${ }^{3}$

In the last fifteen years, an alternative material called "mineral trioxide aggregate (MTA)" became available for use in endodontic procedures of permanent teeth such as pulp capping, pulpotomy, partial pulpotomy, as a root filling material following pulpectomy, to fill wide open apices in immature teeth, to repair perforations and root fractures, and as a retrograde root filling material. It was reported that MTA has good physical characteristics ${ }^{4}$ and induces hard tissue formation in cases of pulpotomy. ${ }^{5}$

This case report describes the clinical and radiographic outcome of the treatment of a mandibular molar with hyperplastic pulpitis using MTA.

\section{Case Report}

A 22-year-old female suffering from profound caries defect in her mandibular right second molar was referred to the Department of Endodontology at the School of Dentistry, Ege University. The intraoral examination revealed neither mobility nor tenderness to percussion. The tooth responded within normal limits to electrical pulp tests. No history of spontaneous pain, mobility or tenderness to percussion was noted. The tooth was asymptomatic, except during mastication when pressure of the food bolus caused mild pain. A hyperplastic pulp tissue was proliferated inside the cavity (Fig. 1a). Radiographic examinations revealed an enlargement towards the periodontal ligament of the tooth (Fig. 2a). The tooth had closed apices. Depending on the clinical and radiographic findings, the mandibular right second molar was diagnosed as hyperplastic pulpitis. The patient was instructed of the possible complications of the procedure. Informed consent was obtained from the patient.

A local anesthetic without vasoconstrictor (Safecaine 3\%; Vem İlaç, Istanbul) was applied for regional anesthesia.
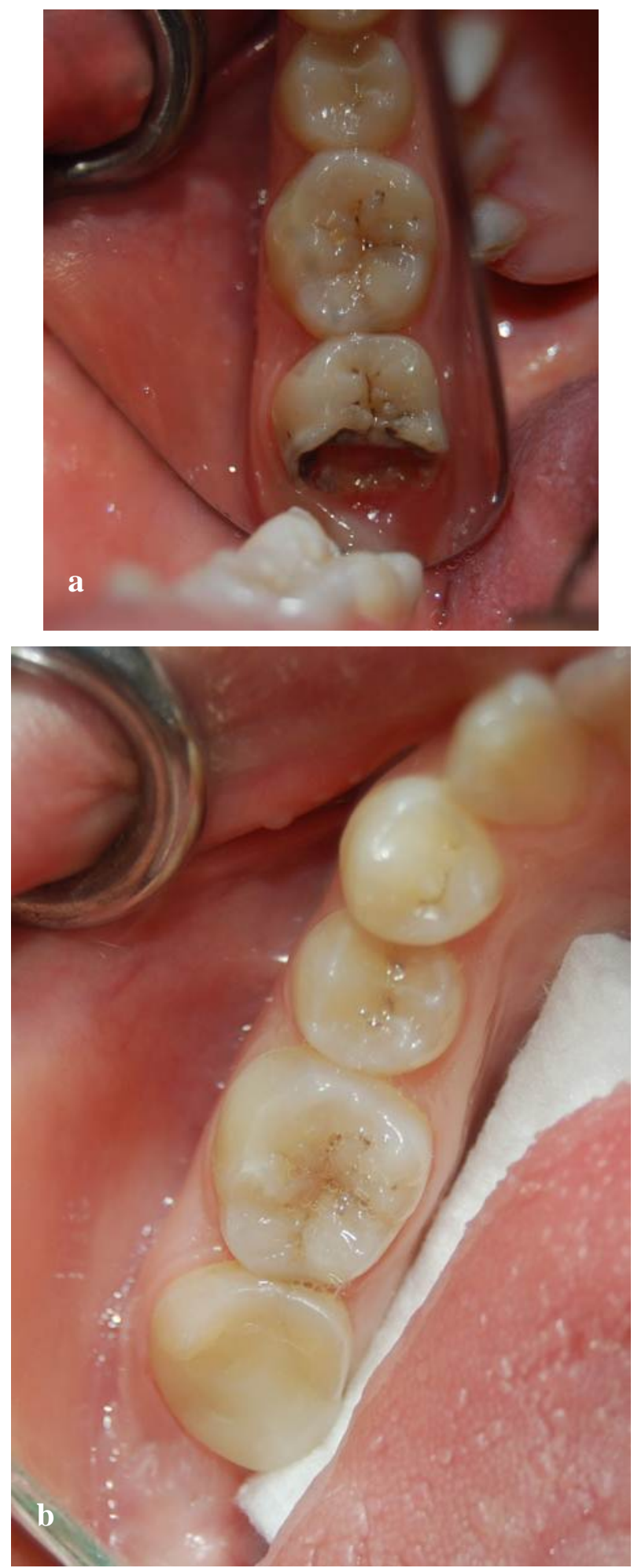

Figure 1. a) Preoperative photograph showing a profound caries in the mandibular right second molar with a proliferation in the pulp. b) Intraoral photograph of the mandibular right second molar with composite resin restoration 

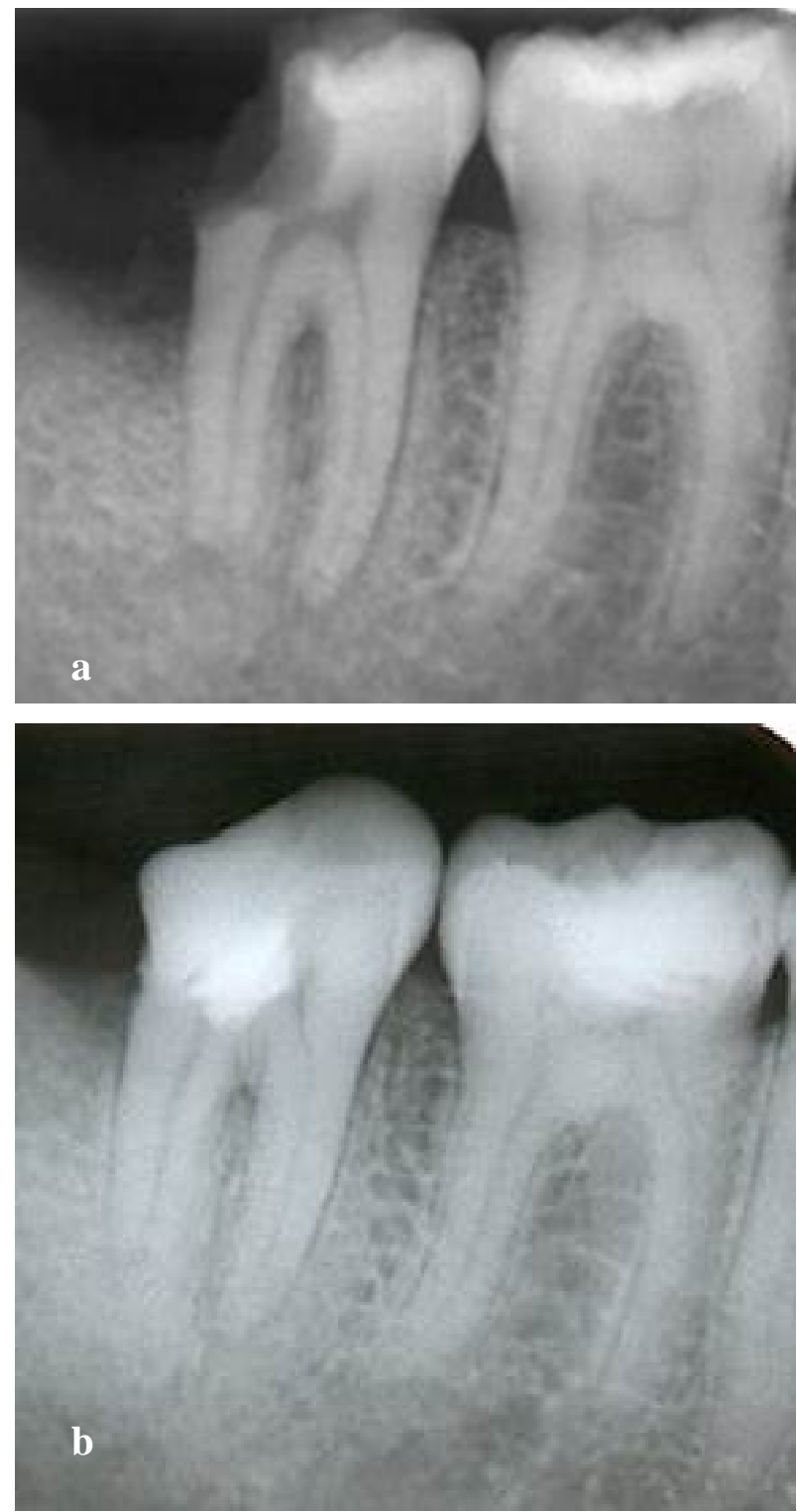

Figure 2. a) Preoperative radiograph showing an enlargement towards the periodontal ligament of the mandibular right second molar. b) Radiograph 12 months after treatment showing a healthy periodontium appearance of the mandibular right second molar.

The treatment included caries removal followed by pulpotomy that was removing the inflamed pulp to orifice level $(\sim 2 \mathrm{~mm})$ with a high-speed round diamond bur accompanied with copious water. Homeostasis was achieved by irrigating the cavity with sterile saline and application of small pieces of sterile sponge pellets, gently. The exposed, blood clot-free pulpal wound was covered with an approximately 2-mm thick layer of white MTA (ProRoot MTA, Maillfer, Dentsply, Switzerland). According to the manufacturer's recommendations, MTA powder was mixed with saline in a 3:1 ratio and then placed over the pulpal wound with a plastic instrument. MTA was then covered with a wet sponge pellet and sealed with zinc oxide-eugenol cement (Austenal, Harrow, UK). After $24 \mathrm{~h}$, patient was recalled to asses if there was any sense of postoperative pain caused by the treated tooth. The zinc oxide-eugenol cement over the set MTA was removed under aseptic conditions, completely and glass ionomer cement $\left(\mathrm{Ketac}^{\mathrm{TM}}\right.$ Molar Aplicap ${ }^{\mathrm{TM}}$, 3M ESPE, St. Paul, USA) was replaced. The tooth was restored with composite resin (Clearfil Majesty; Kuraray Medical, Tokyo, Japan) permanently (Fig. 1b).

The clinical and radiographic examinations after 12 months were carried out to reveal any signs of inflammation. The tooth mobility was within the normal physiological range, percussion test was negative and the patient was asymptomatic. Radiographic examination showed healthy periodontium appearance (Fig. 2b)

\section{Discussion}

The ideal material for vital pulp treatment should resist bacterial leakage and stimulate the remaining pulp tissue for dentin bridge formation. It is clear in endodontic literature that bacterial contamination and infection are the prime threats to pulpal healing. ${ }^{6}$ Therewithal; marginal leakage was indicated as the main reason for failure in vital pulp therapies. $^{6}$ As a consequence, immediate construction of permanent restoration may affect the success of the treatment.

Calcium hydroxide has been the prominent material for vital treatments. ${ }^{2}$ It was indicated that the success rates of calcium hydroxide treatment ranged between $50-90 \% .^{7}$ Calcium hydroxide must be in contact with the vital pulp tissue to stimulate dentin bridge formation. ${ }^{7}$ Due to its high alkaline potential, a necrotic 
zone is formed adjacent to the material in the first instance and in response to the material a dentine bridge is formed against the necrotic zone. $^{2}$

Several studies have shown successful results when MTA has been used for pulpotomies ${ }^{5}$ and in animal and human studies it was also demonstrated that MTA produced less inflammation and less pulpal necrosis compared with calcium hydroxide. ${ }^{5,8}$ Nevertheless, there is no study that suggests partial pulpotomy with MTA in treatment of hyperplastic pulpitis of a permanent molar. Although it has been revealed that the chance of success in vital treatment decreases with aging of the pulp, there are studies showing a high success rate of partial pulpotomy and calcium hydroxide for older age groups. ${ }^{9}$ This case report indicated that the use of the proper material will allow healing even in the aged pulp with mature roots.

In this study the follow-up period was 12 months. Even though, it is recommended to follow up the cases of vital treatment for long time periods to evaluate the success rate, it was also suggested that 3 months would be adequate for a tentative outcome of the treatment. ${ }^{10}$

\section{Conclusion}

MTA may be useful as a substitute for calcium hydroxide in pulpotomy procedures of permanent molar teeth with hyperplastic pulpitis.

This case report showed that MTA is an effective vital pulp therapy agent for treating human permanent molars with hyperplastic pulpitis, relieving associated pulpal symptoms and preserving pulp vitality. It is able to stimulate hard tissue bridge formation. Further researches with longer follow up are needed to clarify the conclusion.

\section{Kaynaklar}

1. Bakland LK. Endodontic considerations in dental trauma. In: Ingle JI, Bakland LK, eds. Endodontics. Toronto: BC Decker Inc; 2002. PP. 795-844.

2. Cohen S, Burns RC, eds. Pathways of the pulp. 7th ed. St. Louis: Mosby; 1998: 808-811.

3. Hanks CT, Bergenholtz G, Kim JS. Protein synthesis in vitro, in the presence of $\mathrm{Ca}(\mathrm{OH}) 2$ containing pulp-capping medicaments. $J$ Oral Pathol 1983;12: 356-365.

4. Torabinejad M, Hong CU, Pitt Ford TR. Physical properties of a new root end filling material. $J$ Endod 1995; 21: 349-354.

5. Dominguez MS, Witherspoon DE, Gutmann JL, Opperman LA. Histological and scanning electron microscopy assessment of various vital pulp-therapy materials. $J$ Endod 2003; 29: 324-333.

6. Massler M. Therapy conductive to healing of the human pulp. Oral Surg Oral Med Oral Pathol Oral Radiol Endod1972; 34: 122-130.

7. Witherspoon DE, Joel C. Small JC, Harris GZ. Mineral trioxide aggregate pulpotomies. A case series outcomes assessment. J Am Dent Assoc 2006; 137: 610-618

8. Aeinehchi M, Eslami B, Ghanbariha M, Saffar AS. Mineral trioxide aggregate (MTA) and calcium hydroxide as pulp-capping agents in human teeth: a preliminary report. Int Endod $J$ 2003; 36: 225-231.

9. Norsat IV, Norsat CA. Reparative hard tissue formation following calcium hydroxide application after partial pulpotomy in cariously exposed pulps of permanent teeth. Int Endod $J$ 1998; 31: 221-226.

10. Matsuo T, Nakanishi T, Shimizu H, Ebisu S. A clinical study of direct pulp capping applied to carious-exposed pulps. $J$ Endod 1995; 22: 551- 556.
Yazışma Adresi:
Dr. Ilgın AKÇAY
Ege Üniversitesi,
Diş Hekimliği Fakültesi,
Endodonti $A D$,
35100 Bornova - IZMIR
Tel : (232) 3880328
E-posta : ilgin.akcay@ege.edu.tr 